\begin{tabular}{|c|c|c|c|c|c|c|}
\hline \multirow{4}{*}{ Impact Factor: } & ISRA (India) & $=4.971$ & SIS (USA) & $=0.912$ & ICV (Poland) & $=6.630$ \\
\hline & ISI (Dubai, UAE & $=0.829$ & РИНЦ (Russia) & $=0.126$ & PIF (India) & $=1.940$ \\
\hline & GIF (Australia) & $=0.564$ & ESJI (KZ) & $=8.716$ & IBI (India) & $=4.260$ \\
\hline & JIF & $=1.500$ & SJIF (Morocco) & $=5.667$ & OAJI (USA) & $=0.350$ \\
\hline
\end{tabular}

\section{SOI: $1.1 /$ TAS $\quad$ DOI: $10.15863 /$ TAS \\ International Scientific Journal Theoretical \& Applied Science}

p-ISSN: 2308-4944 (print) e-ISSN: 2409-0085 (online)

Year: $2020 \quad$ Issue: 03 Volume: 83

Published: $30.03 .2020 \quad$ http://T-Science.org
QR - Issue

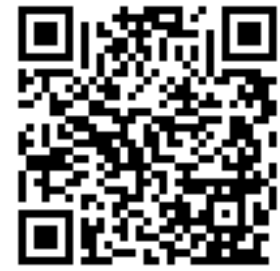

QR - Article

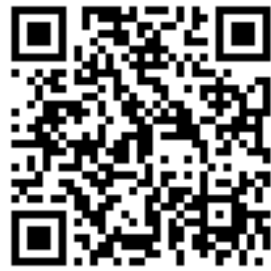

Nasiba Orzuyevna Abdullayeva

The Bukhara Engineering and technological institute A teacher of

Foreign Languages Department +99891 440-38-72

nasiba.abdullayeva.2018@mail.ru

\title{
PEDAGOGICAL-PSYCHOLOGICAL CLASSIFICATION OF ABILITY
}

Abstract: ability - a person's individual-psychological characteristics, ability to perform certain activities and successful performance of work is the sum of individual mental qualities that represent subjective conditions. Identifies differences in the dynamics of acquiring the necessary knowledge, skills and abilities. Abilities are an individual-psychological feature because of the other qualities and characteristics of the person, i.e. the mind qualities, memory and character traits, emotions should not be opposed, but should be put in line with them. Ability is not innate, a gift of nature, but is formed throughout one's life.

Key words: ability, individual-psychological characteristics, knowledge, skills, mind qualities, memory and character traits, emotions.

Language: English

Citation: Abdullayeva, N. O. (2020). Pedagogical-psychological classification of ability. ISJ Theoretical \& Applied Science, 03 (83), 371-375.

Soi: http://s-o-i.org/1.1/TAS-03-83-69 Doi: crosłef https://dx.doi.org/10.15863/TAS.2020.03.83.69

Scopus ASCC: 3304.

\section{Introduction}

Howard Gardner called abilities a set of intellects and highlighted its seven aspects. We are from these aspects of intellect we can analyze six of them in terms of improving the pedagogical skills of teachers. This is the psychologist Olga Matveeva modifies and enhances aspects with psychological technology emphasizes the importance of the teacher's professional career and demonstrates the following skills.

1. Ability to communicate. Teacher students with lessons and extracurricular activities, a positive mental climate in the classroom can create.

2. Ability to anticipate events. This type of ability is internal to the psyche of the students can be seen in the world. Then the teacher can predict who is capable of what.

3. Ability to hear and feel. He/she had that ability people love music, feel the melody well, recitation based on good reading of prose and poetry, memorizing what they hear preserves, especially loves to listen to poems and songs.

4. Kinesthetic (skin-muscle) ability. The teacher's ability to coordinate his or her own behaviors while feeling the tone of the action directs, feels time through action, life for himself can create comforts, knows how to enjoy the blessings of life.

5. Logical ability. Philosophical reflections, numbers loves math, solving complex problems, causation and has the ability to understand the consequences of the consequences, in reality can distinguish the primary from the secondary.

6. The inner ability of a person. The ability to know, understand and feel perfectly, the inner ability of a free person is perfect develops, strong-willed, determined, has his own opinion in any situation can freely express their opinion.

\section{II.Literature review}

Ability characterizes the individual capabilities of the teacher. In the same way, talented teachers are talented in their work they achieve more than lower ones. Ability is faster in both general and specific development of an individual moving forward, most of his executive and creative activities ensures high results. A talented person can quickly acquire a specialty and achieve high skills and work output, innovation in science or culture. Ability is different 


\begin{tabular}{|c|c|c|c|c|c|c|}
\hline \multirow{4}{*}{ Impact Factor: } & ISRA (India) & $=4.971$ & SIS (USA) & $=0.912$ & ICV (Poland) & $=6.630$ \\
\hline & ISI (Dubai, UAE & $=0.829$ & РИНЦ (Russia & $=0.126$ & PIF (India) & $=1.940$ \\
\hline & GIF (Australia) & $=0.564$ & ESJI (KZ) & $=8.716$ & IBI (India) & $=4.260$ \\
\hline & JIF & $=1.500$ & SJIF (Morocce & $=5.667$ & OAJI (USA) & $=0.350$ \\
\hline
\end{tabular}

from knowledge. Knowledge is the result of scientific reading, and ability is inherent in the psychological and physiological structure of man is a feature that ability is a necessary condition for learning at the same time, it is a product of a certain level of knowledge. In the process of acquiring general and special knowledge, as well as acquiring professional skills, the ability is perfected and developed. Concepts that are closer to ability are skills and competencies. Skills are the perfect way to work based on the experience and knowledge gained in the course of a teacher's professional career.

\section{III.Analysis}

Skills are a set of automated components of professional intellectual activity created in the process of a teacher's conscious activity. They form the basis of the mechanism of the teacher's professional activity processes, along with the ability to achieve pedagogical skills as a result of which teachers achieve great success in their professional careers. Talented, but with skills and abilities A teacher who doesn't have one can't achieve much. Ability occurs in the deep acquisition of skills and competencies. Indeed, the skills and abilities of a gifted person will be multifaceted and perfected. Skills and competencies may be supplemented by a lack of ability or a lack of ability can fix. Generalization of skills is also called mastery. Mastery is also a skill. This means that ability is formed in the process of developing your skills and competencies.

In pedagogy, the ability of the teacher is an opportunity, the necessary level of his skill is developed only in the process of teaching and education, and lays the foundation for success. Innate abilities are called intelligence. Talent, talent, genius the creative activity of man are stages in the development of skills acquired in the process. Abilities, like character, are qualities that a person has only in certain activities. Ability in psychology is the ability of a person to acquire professional knowledge, skills and abilities without difficulty, easily and perfectly is said to deal successfully with. He/she is a teacher by profession in his/her work. The qualities of professional activity that determine the content of education are reflected in the creativity of the teacher. Creativity is qualitatively new, is an activity that creates an original and unique innovation. Any problem identified in productive creativity is solved successfully; teachers who are capable of creativity in the main part these aspects are manifested. Heuristic creativity refers to professional activities that take place in society it means the bold assimilation and promotion of innovation, i.e. its to intensify the process of generating ideas (hypotheses) based on and consistent their proximity (probability, reliability) to reality the ability to exercise and act boldly in a new situation, the development of thinking based on the process of thinking is observed. In creative work, the teacher has a social significance creates new theories, comes up with their own ideas and suggestions, is a master and only experienced, qualified teachers can gain knowledge. Signs of natural anatomicalphysiological ability forms the physiological basis, which then becomes an ability The set of signs of ability is called human talent. The sum of the processes of signs of knowledge and ability in man, the pinnacle of his/her talent is his/her intellect.

Basic qualities and characteristics of pedagogical ability. In pedagogical psychology, the ability of the teacher is limited, there are no species. Types of pedagogical abilities can increase and change depending on the development of science and society. Ability in philosophy long-term "unchanging heredity" is a process that is passed down from generation to generation interpreted as. As a result of many years of research and observations by scientists, the following of pedagogical ability. The main qualities are highlighted:

1. Love of profession, ability to love students.

2. Excellent knowledge of the subject, interest in it. beauty).

3. To have pedagogical tact (decency and

4. Ability to integrate into the children's community.

5. A creative approach to their work.

6. A sense of responsibility.

7. Acquisition of educational knowledge.

Specific systems of pedagogical ability in teaching there is. The ability system is distinguished by the following features:

- key features;

- basic features;

- leading features;

- auxiliary features.

\section{IV.Discussion}

Pedagogical skills are only effective in pedagogical activities without expressing its existence and conditions, but in many respects it is also the result of successful work. In pedagogical ability, the characteristics of the teacher related to the exchange of ideas play a key role. The main features of the following pedagogical abilities are constantly formed as a result of high pedagogical and psychological knowledge of the teacher:

1.Communicative ability: the teacher's interaction with the teaching staff and parents, the community, their mental understanding their circumstances and empathizing with them as they engage in communication pure volunteering. The teacher must have psychological knowledge, should form a culture of behavior on a regular basis.

2. Perceptual ability: perception, perception of the external world and environment, that is, observation plays an important role. It develops and improves as a result of the teacher's enthusiasm. The 


\begin{tabular}{|c|c|c|c|c|c|c|}
\hline \multirow{4}{*}{ Impact Factor: } & ISRA (India) & $=4.971$ & SIS (USA) & $=0.912$ & ICV (Poland) & $=6.630$ \\
\hline & ISI (Dubai, UAE & $=0.829$ & РИНЦ (Russia) & $=0.126$ & PIF (India) & $=1.940$ \\
\hline & GIF (Australia) & $=0.564$ & ESJI (KZ) & $=8.716$ & IBI (India) & $=4.260$ \\
\hline & JIF & $=1.500$ & SJIF (Morocco) & $=5.667$ & OAJI (USA) & $=0.350$ \\
\hline
\end{tabular}

teacher perceives the psychology of the student, his mental state, the state of the class gives a fair assessment of the pedagogical situation.

3. Empathic ability: stemming from love for children to feel the feelings, psychological states of students from the heart, understanding, comprehending, empathizing with them.

4. Ability to alternate the learning process: the teacher's own conveying knowledge to the reader's mind and thinking at the expense of less effort to achieve the goal in a timely manner in education and upbringing ability.

5. Didactic ability: in-depth communication with students, in-depth study of pedagogical laws and methods of pedagogy is the ability to teach effectively while mastering. Also a lesson to world standards, modern on the basis of pedagogical technologies must meet the requirements.

6. Organizational ability: is an integral part of pedagogical ability. She/he has been involved in various community activities by the class teacher, is active in engaging every student in the class community in engaging in clubs is reflected in the provision of the situation.

7. Constructive ability: the teacher's educational activitya professional pedagogical situation that arises on the basis of careful planning be able to anticipate the steps.

8. Ability to know. The teacher is deep in his/her subject and other subjects to know, master and demonstrate in practice.

9. Ability to comprehend: the teacher's intelligence and resourcefulness, deep understanding of events and happenings, and fair treatment of them.

Basic features of pedagogical skills observation:

- This is the ability to see the specific side of an individual thing, the starting material for creative activity;

- The observation of the artist, from the observation of the naturalist;

- The difference is obvious. Their observation varies each has its own way of thinking and thinking.

- A leading feature of talent is creative imagination. This feature is only available to artists, math teachers, and literary critics not only specific, but also applicable to all science teachers. It takes skill to master the secrets of any profession perfectly.

Pedagogical ability is formed only in a healthy teacher. However can be high, medium and low. These are different levels some of the qualities and attributes that are embodied in abilities plays a supporting role. Ancillary features included in the system of pedagogical skills and attributes include:

- certain types of perception;

- responsiveness;

- to shortcomings critical attention;

- stability;

- teacher's speech: oratory, vocabulary depth;
- acting features: facial expressions and pantomime, imaginary to be able to use fantasy, to control mental emotions;

- pedagogical tact and pedagogical decency.

Pedagogical influence is the ability to communicate as the main method. After gaining socio-political independence in the Republic of Uzbekistan, in all spheres of life, including education radical reforms are taking place and huge changes are taking place. Reforms serves to build a democratic, humane, legal society recognized as the path of development and progress of the republic. The task of building a democratic, humane, legal society is the responsibility of the younger generation. Law of the Republic of Uzbekistan "On Education", "National Training Program" and speeches of the first President I.A. Karimov and Education and upbringing in a number of works declared a priority in the field of development, its goals and objectives defined. Pedagogical influence is an important communicative tool for the teacher is one of the skills, primarily based on the culture of the teacher's appearance, attitude and speech culture in the process of conducting regular educational activities with students appears.

Pedagogical influence - the development of conscious discipline and independent thinking skills in the pupil, the purpose of education regular and systematic influence on the individual for the proper development, comprehensive development of the individual by approaching the socio-historical experiences of society, improvement of his behavior and worldview, upbringing of the younger generation on the basis of specific goals, social consciousness and behavior of the rich ideologies of our people to form on the basis of is a process of focused activity. On the basis of pedagogical influence the pupil's consciousness is formed, spiritual wealth and feelings are developed, in which the social connections necessary for social life are formed. Behavioral habits are formed that serve to the pedagogical impact that society places on the individual formed moral skills and habits that meet ethical requirements is done. To the mind, emotion, and will of the student to achieve this affected. If any of these are overlooked, it will be difficult for the teacher to achieve his or her educational goals. The educational process is led by a teacher. It defines the activities of students, creates conditions for their participation in the pedagogical process. The essence of education is expressed in the context of pedagogical influence and its content comes from the social goals of the country based out. The essence of upbringing is expressed differently in different periods. However, they represent similar ideas in terms of orientation. After all, the development of any nation, the strength of states depends in many ways on the upbringing of generations has long been proven. In any social society, the upbringing of the younger generation is organized on the basis of a specific goal. The purpose 


\begin{tabular}{|c|c|c|c|c|c|c|}
\hline \multirow{4}{*}{ Impact Factor: } & ISRA (India) & $=4.971$ & SIS (USA) & $=0.912$ & ICV (Poland) & $=6.630$ \\
\hline & ISI (Dubai, UAE & $=0.829$ & РИНЦ (Russia & $=0.126$ & PIF (India) & $=1.940$ \\
\hline & GIF (Australia) & $=0.564$ & ESJI (KZ) & $=8.716$ & IBI (India) & $=4.260$ \\
\hline & JIF & $=1.500$ & SJIF (Morocce & $=5.667$ & OAJI (USA) & $=0.350$ \\
\hline
\end{tabular}

of education is the development of social society, its direction of development, the content of social relations determined by origin. Today in the Republic of Uzbekistan the main purpose of organized education is to bring up a perfect person maturity. The main pedagogical methods of pedagogical influence are from life, based on the way of life of the nation, national traditions and customs is selected. They aim to educate students pedagogically chooses in terms of appropriate organization. Pedagogical influence is the socially useful work of students activities in accordance with a pedagogically specific goal consists of a system of tools used to organize. This the tools are targeted at the learner and the learner shapes behavior. Pedagogical influence of the teacher in the process of teaching and education main methods of presentation: demand, prospects, incentives and punishment, public opinion.

Requirement - the teacher in the process of teaching and educating the pupil in a relatively personal relationship. The student is either this behavior is under the control of the teacher and the positive aspects are encouraged or, conversely, the negative behaviors are stopped. Perspective is an effective pedagogical method that is independent of students improves thinking, a sense of freedom to pursue a particular goal, a dream. These goals are in their personal aspirations, interests and will be reflected in the This method is personal to school students develops a sense of purpose, which is one of the most important human qualities. Incentives and punishments are the most traditional form of education is a method that has a positive effect on student behavior. Good manners, useful work and behavior, moral character, assignments the student is encouraged to do it unconditionally. Misconduct, disorder, and misconduct can be remedied through punishment are given. This method provides a moral impact, to apply it extreme caution, sensitivity and vigilance from the teacher in the process required. Public opinion is the most important factor in educating method, which is manifested in the regular encouragement of students based on the results of their socially useful activities. To carry out the educational tasks of the team in a certain direction provides a friendly relationship between students. The most effective use of pedagogical methods an important condition requires a teacher's approach from a humanitarian perspective. These methods are a lively response of living people to a single aspiration that feels professional responsibility. Pedagogical the impact is focused on an incomprehensible area of the student's psyche that is in close contact with the educator and the learners that they will trust each other, that they will understand each other the content of the impact, the practical impact on the overall state of the individual implies.

\section{V.Conclusion}

Thus, the impact is educational effectiveness guidance in improving at the level of modern requirements encourages student activism by creating. The teacher is aware of the interactions between students, their interactions and activities the existence of a link between, determines its effectiveness must not forget. The teacher to the class team and the individual student in order to succeed in pedagogical influence, it is necessary to rationally plan the system of pedagogical relations between students and change the psychological environment in a positive way. In order to create a system of pedagogical relations that is organized and perfect in all respects, aimed at preserving the minds of the younger generation, educating them in the spirit of national and universal values, the teacher should have a deep understanding of the psyche of each student, be aware of their inner potential, provide information, exchange ideas, understand their grief, feelings, and empathy. To succeed in the pedagogical approach, the teacher must analyze the following:

- be able to model future relationships with students;

- predict the class community properties to be treated to know;

- establish a relationship based on direct sincerity and solidarity;

- has an advantage in the relationship, based on democratic requirements rational management; relationship.
- positive and negative aspects of the

\section{References:}

1. Azizxo'jayeva, N.N. (2003). "Pedagogik texnologiya va pedagogik mahorat”. (p.174). Tashkent: TDPU.

2. (n.d.). Approaches to Teaching English as a Second Language. Retrieved from www.aubrun.edu/ nunnath/engl6240/fonf.html
3. Willis, J. (1996). A Framework for TaskedBased Learning. London: Longman.

4. Wills, J. (2000). Task-based Language Teaching: teachers' solutions to problems.

5. Harmer, J. (2001). The Practice of English Language Teaching. Harlow: Longman.

6. Jolly and Bolitho R. (2000). Material design. 


\begin{tabular}{|c|c|c|c|c|c|c|}
\hline \multirow{4}{*}{ Impact Factor: } & ISRA (India) & $=4.971$ & SIS (USA) & $=0.912$ & ICV (Poland) & $=6.630$ \\
\hline & ISI (Dubai, UAE & $=0.829$ & РИНЦ (Russia & $=0.126$ & PIF (India) & $=1.940$ \\
\hline & GIF (Australia) & $=0.564$ & ESJI (KZ) & $=8.716$ & IBI (India) & $=4.260$ \\
\hline & JIF & $=1.500$ & SJIF (Morocec & $=5.667$ & OAJI (USA) & $=0.350$ \\
\hline
\end{tabular}

7. (2001). Kumaravadivelu. Language - learning tasks: teacher intention and learner.

8. (2001). Marianne Celcie Murcia (Editor). Teaching English As a Second or Foreign.

9. (n.d.). Metodika prepodovanija inostrannih jazikov zarubezhom. "Progress"

10. Otaboyeva, M.R. (2017). Chet tilini o'qitishda zamonaviy innovatsion texnologiyalaridan foydalanish va uning samaradorligi. Molodoj uchenyj, №4.2, pp.

36-37.

https://moluch.ru/archive/138/39058/

11. Ishmuhamedov, R. (2005). "Innovatsion texnologiyalar yordamida ta'lim samaradorligini oshirish yo'llari". Toshkent: "Nizomiy". TDPU.

12. Matmurotova, Z. (2017). Chet tillarni o`rgatish samaradorligini oshirish usullari. Molodoj uchenyj, №24.2,

https://moluch.ru/archive/158/44684/ 